Kredo 4 (2021)
KREDO: Jurnal Ilmiah Bahasa dan Sastra
Terakreditasi Sinta 4 berdasarkan Keputusan Direktorat
Jenderal Penguatan Riset dan Pengembangan,
Kementerian Riset, Teknologi dan Pendidikan Tinggi
Republik Indonesia
Nomor: 23/E/KPT/2019. 08 Agustus 2019
https://jurnal.umk.ac.id/index.php/kredo/index

\title{
KAJIAN FEMINISME DALAM NOVEL CINTA 2 KODI KARYA ASMA NADIA
}

\author{
Dita Ariaseli ${ }^{1}$, Yenny Puspita ${ }^{2}$ \\ dithaaryaselly@yahoo.com ${ }^{1}$, yenny_puspitaa@yahoo.com²
}

Universitas PGRI Palembang, Indonesia

Info Artikel
Sejarah Artikel
Diterima
14 Februari 2020
Disetujui
21 Juni 2020
Dipublikasikan
17 April 2021

Keywords
feminism, social-
cultural, economically,
religiously,
educationally.
Kata Kunci
kajian feminisme, aspek sosial-kultural, aspek ekonomi, aspek agama, aspek pendidikan.

: Abstract

This research intend to know and describe feminism in novel Cinta 2 Kodi by Asma Nadia in regards to social-cultural, economy, religion, education. The method used for this research is descriptive. The technique for collecting data is documentation. The content validity use triangulation. This research use content analysis as technique for analyzing data. It was found in this research that there was some feminism found in this novel seen from the social-cultural which show that female was not always "the number two" after male. Female is comparable to male as long as they work hard. Economically, female could also work in public just like male. Female could perform double role as housewives or career women. Religiously, both male and female can pray. Success is also the result of their prayer. Educationally, having a higher education is not a must for

: female because in the end they will become a houswife. However, as long as they have faith on their abilities, they will have a bright future just like male.

\section{1 | Jurnal Kredo}

Vol. 4 No. 22021 


\begin{tabular}{|c|c|c|}
\hline & $\begin{array}{c}\text { Kredo 4 (2021) } \\
\text { KREDO: Jurnal Ilmiah Bahasa dan Sastra } \\
\text { Terakreditasi Sinta } 4 \text { berdasarkan Keputusan Direktorat } \\
\text { Jenderal Penguatan Riset dan Pengembangan, } \\
\text { Kementerian Riset, Teknologi dan Pendidikan Tinggi } \\
\text { Republik Indonesia } \\
\text { Nomor: 23/E/KPT/2019. 08 Agustus 2019 } \\
\text { https://jurnal.umk.ac.id/index.php/kredo/index }\end{array}$ & $\begin{array}{l}\square \\
\square \\
\square \\
\square \\
\square\end{array}$ \\
\hline
\end{tabular}

\section{PENDAHULUAN}

Novel adalah karangan prosa yang panjang mengandung rangkaian cerita kehidupan seseorang dengan orang di sekelilingnya dengan menonjolkan watak dan sifat setiap pelaku (Departemen Pendidikan Nasional, 2008). Sama halnya menurut (Sugihastuti, 2002), novel adalah struktur yang bermakna, novel tidak sekadar merupakan serangkaian tulisan yang menggairahkan ketika dibaca, tetapi merupakan struktur pikiran yang tersusun dari unsur-unsur yang padu. Salah satu pendekatan dalam menganalisis novel adalah feminisme.

Analisis feminisme muncul karena kesadaran ketidakadilan dan hak-hak dasar kehidupan kaum perempuan. Suara-suara subordinasi perempuan bergema pada saat pasca revolusi industri di Eropa. Di dunia sastra Indonesia, feminisme sudah dipermasalahkan sejak tahun 20-an, yaitu dalam roman "Siti Nurbaya" bertema kawin paksa. Dalam segala hal, kaum perempuan dianggap manusia yang tidak mempunyai kehendak dan keyakinan dan hanya menurut kehendak kaum laki-laki (Darma, 2009).

Feminisme muncul dari rasa ketidakpuasan terhadap sistem patriarki yang ada pada masyarakat. Patriarki menentukan bahwa laki-laki superior dan perempuan inferior (Selden dikutip Darma, 2009:140).
An opinion from Pateman dalam (Narasati, 2019)), women are what they are by nature. Men must create themselves in public life, and they are endowed with the masculine capacity to do so. While women must remain in the natural private sphere of the family and the family is represented in public by the husband or the 'one person' created by marriage contract. With sexual difference that entails a patriarchal division of labor, the husband has the prerogative to go out and work for the family's living. They are also included to attend to its needs and deserve to control and administer its capital.

Perempuan dalam pandangan feminisme mempunyai aktivitas dan inisiatif sendiri, untuk memperjuangkan hak dan kepentingan tersebut dalam berbagai gerakan. Masalah-masalah yang dihadapi perempuan, mendorong perempuan untuk melakukan protesprotes, dan melawan diskriminasi yang selama ini diderita (Darma, 2009).

Perempuan yang dekat dengan konteks feminisme, dalam era postmodern tidak lagi menitikberatkan pada bagaimana perempuan bisa tertindas oleh konstruksi budaya patriarki. Akan tetapi, lebih mempertanyakan bagaimana kita mengonstruksi konsep perempuan (Krissandi, 2019).

Gerakan feminisme berkembang pesat hampir di seluruh penjuru dunia. Di Amerika munculah publikasi John 


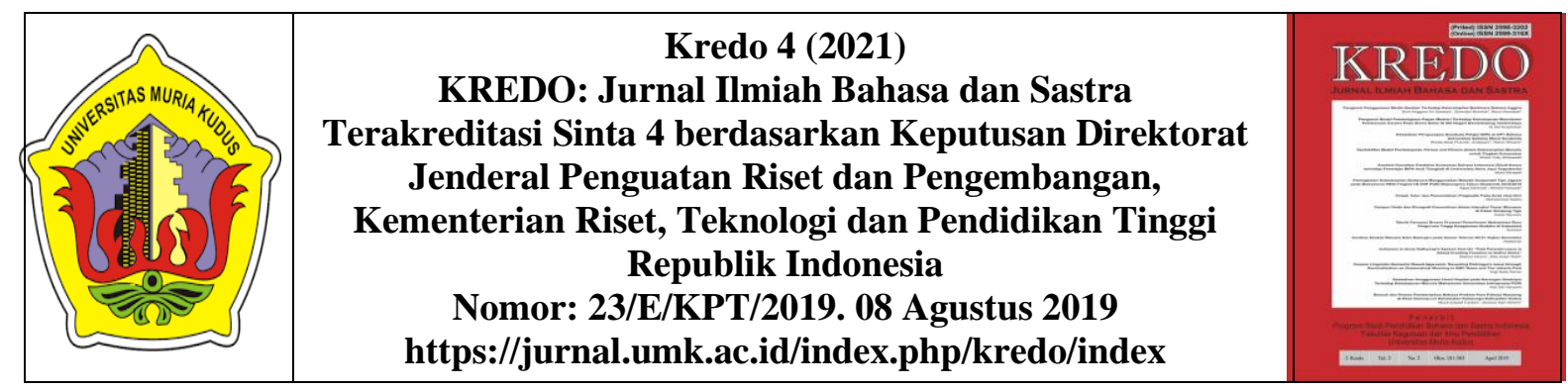

Stuart Mill (1869) yang berjudul The Subjection of Women, gerakan ini menandai kelahiran feminisme gelombang pertama. Gerakan gelombang kedua, tahun 1960. Pada saat itu pertama kali perempuan diberi hak suara di parlemen, hak pilih, dan boleh ikut dalam ranah politik kenegaraan (Broto dikutip (Darma, 2009)).

Perjuangan gerakan feminisme berkembang lebih lama lagi dengan tuntutan untuk mencapai kesederajatan dan kesetaraan harkat, serta kebebasan perempuan untuk memilih dalam mengelola kehidupan dan tubuhnya baik di ruang domestik maupun di ruang publik (Darma, ,2009).

Berdasarkan uraian di atas, peneliti memilih novel Cinta 2 Kodi karya Asma Nadia karena novel ini tercermin jati diri perempuan Indonesia yang memiliki kemandirian yang sama besar dengan laki-laki, novel ini mencerminkan pula sosok perempuan yang memiliki prestasi. Selain itu, dari sisi pengarang, Asma Nadia adalah salah satu penulis wanita yang mampu menarik perhatian masyarakat dengan karya-karya yang fenomenal. Beberapa dari novelnya bahkan diangkat ke layar lebar menjadi sebuah film. Prestasi Asma Nadia memang sudah tidak diragukan lagi, prestasi yang dihimpun Asma Nadia dari berbagai karyanya sudah sangat banyak, ia sudah sering memenangkan berbagai lomba di ajang nasional maupun internasional. Salah satu bukunya yaitu Rembulan di Mata Ibu menjadi pemenang dalam kategori buku remaja terbaik tahun 2001. Selain itu, Asma juga berhasil meraih penghargaan dari Mizan Award karena keberhasilan dua buah karyanya yang masuk dalam antologi cerpen terbaik di majalah Annida. Asma Nadia juga aktif melakukan perjalanan baik di dalam maupun luar negeri untuk menjadi pembicara di berbagai acara. Kemampuannya yang sudah sangat diakui membuatnya menjadi salah satu tokoh yang bisa menularkan inspirasi dan ilmu terutama di bidang sastra. Sementara kelebihan novel Cinta 2 Kodi karya Asma Nadia ini yaitu novel ini terinspirasi dari kisah nyata yang menggambarkan tentang perempuan yang berjuang keras menyelamatkan rumah tangganya demi impian dan cintanya kepada suami dan anakanaknya. Selain itu novel ini juga menceritakan tentang perjalanan hidup seorang perempuan tangguh bernama Kartika dalam membangun keluarga dan membesarkan bisnisnya. Kartika adalah seorang pemilik usaha busana muslim merek 'keke' yang mulai ia rintis dari awal dengan melewati berbagai macam cobaan dalam bisnisnya, berbekal tekad dan perjuangannya sehingga bisnisnya bisa berkembang menjadi usaha yang besar dan sukses. Setiap rangkaian cerita di dalam novel tersebut disusun oleh 


\begin{tabular}{|c|c|c|}
\hline & $\begin{array}{c}\text { Kredo 4 (2021) } \\
\text { KREDO: Jurnal Ilmiah Bahasa dan Sastra } \\
\text { Terakreditasi Sinta } 4 \text { berdasarkan Keputusan Direktorat } \\
\text { Jenderal Penguatan Riset dan Pengembangan, } \\
\text { Kementerian Riset, Teknologi dan Pendidikan Tinggi } \\
\text { Republik Indonesia } \\
\text { Nomor: 23/E/KPT/2019. 08 Agustus 2019 } \\
\text { https://jurnal.umk.ac.id/index.php/kredo/index }\end{array}$ & $\begin{array}{l}\square \\
\square \\
\square \\
\square \\
\square\end{array}$ \\
\hline
\end{tabular}

pengarang menggunakan alur cerita yang dibuat dengan menarik. Dengan demikian, penulis tertarik untuk menganalisis novel Cinta 2 Kodi karya Asma Nadia yang ditinjau dari segi feminisme.

Adapun tujuan penelitian ini adalah untuk mengetahui dan mendeskripsikan feminisme dalam novel Cinta 2 Kodi karya Asma Nadia yang meliputi aspek sosial-kultural, aspek ekonomi, aspek agama dan aspek pendidikan.

Masalah yang dibahas dalam penelitian ini adalah bagaimanakah gambaran feminisme yang terdapat dalam novel Cinta 2 Kodi karya Asma Nadia yang meliputi aspek sosialkultural, aspek ekonomi, aspek agama dan aspek pendidikan.

Kajian pustaka yang relevan sebagai bahan referensi penelitian oleh penulis. Penelitian tentang feminisme dalam karya sastra pernah dilakukan oleh Sapitri Fransiska, mahasiswa Program Studi Pendidikan Bahasa dan Sastra Indonesia, FKIP Universitas PGRI Palembang, angkatan 2009, dengan judul skripsi, "Feminisme dalam Novel Secuil Hati Karya Fani Krismawati: Hasil penelitiannya menyatakan bahwa feminisme dalam novel Secuil Hati Wanita di Teluk Eden karya Fani Krismawati ini terdiri dari empat aspek, yakni aspek sosialkultural, pengarang menggambarkan kehidupan tokoh perempuannya saling mempunyai hubungan yang erat antarmasyarakat. Pengarang menggambarkan hubungan tersebut pada masa kanak-kanak dan pada masa remaja, pengarang menggambarkannya dengan kehidupan yang dialami para tokohnya. Selanjutnya aspek ekonomi, pengarang menggambarkan kehidupan para tokoh perempuannya hidup kemiskinan tanpa kemewahan atau berfoya-foya.

Pengarang menggambarkan Dela Eden perempuan yang hidup dengan sederhana. Pengarang juga menggambarkan sosok Dela Eden perempuan yang sangat kuat. Kemudian pada aspek pendidikan, pengarang menggambarkan tingkat pendidikan pada ceritanya dengan latar pendidikan yang rendah, yang mengakibatkan sulit untuk mengembangkan potensi yang ada pada dirinya. Pengarang menggambarkan pendidikan para tokohnya dengan pendidikan yang tidak terlalu tinggi. Hal ini mengakibatkan tokoh-tokoh pada novel Secuil Hati Wanita di Teluk Eden karya Fani Krismawati sangat memilukan. Para tokohnya tidak pernah mengenyam pendidikan yang seharusnya diterimanya. Sedangkan pada aspek hukum, pengarang menggambarkan sebagian besar ceritanya pada pelecehan dan teraniaya terhadap perempuan. Banyak sekali pelanggaran-pelanggaran HAM yang terjadi pada cerita novel ini. Hal tersebut bisa dilihat dari perempuan 


\begin{tabular}{|c|c|c|}
\hline & $\begin{array}{c}\text { Kredo 4 (2021) } \\
\text { KREDO: Jurnal Ilmiah Bahasa dan Sastra } \\
\text { Terakreditasi Sinta } 4 \text { berdasarkan Keputusan Direktorat } \\
\text { Jenderal Penguatan Riset dan Pengembangan, } \\
\text { Kementerian Riset, Teknologi dan Pendidikan Tinggi } \\
\text { Republik Indonesia } \\
\text { Nomor: 23/E/KPT/2019. 08 Agustus 2019 } \\
\text { https://jurnal.umk.ac.id/index.php/kredo/index }\end{array}$ & $\begin{array}{l}\square \\
\square \\
\square \\
\square \\
\square\end{array}$ \\
\hline
\end{tabular}

yang selalu disiksa oleh suaminya sendiri.

Adapun persamaan antara penelitian yang dilakukan oleh Sapitri dengan penelitian yang dilakukan oleh penulis adalah terletak pada bidang kajiannya, yakni sama-sama menganalisis feminisme dalam karya sastra yang berbentuk novel. Perbedaannya, terletak pada objek dan aspek kajian yang diteliti. Sapitri meneliti novel Secuil Hati Wanita di Teluk Eden karya Fani Krismawati dengan aspek yang ditelitinya adalah aspek sosial-kultural, aspek ekonomi, aspek pendidikan, dan aspek hukum. Sedangkan penulis melakukan kajian terhadap novel yang berjudul Cinta 2 Kodi karya Asma Nadia dengan aspek sosial-kultural, aspek ekonomi, aspek agama dan aspek pendidikan.

Selain itu, penelitian yang serupa juga pernah dilakukan oleh R. A. Choirunnisa, mahasiswa Universitas PGRI Palembang, angkatan 2011 dengan judul skripsi, "Analisis Feminisme dalam Novel Rembang Jingga Karya TJ. Detoro dan Dwiyana Premadi". Perbedaan antara penelitian yang dilakukan oleh R. A. Choirunnisa dengan penelitian yang dilakukan oleh pernulis adalah objek kajian dan fokus penelitian yaitu R. A. Choirunnisa lebih memfokuskan penelitiannya pada feminisme radikal dan liberal, sedangkan fokus penelitian yang dikaji penulis adalah aspek sosial-kultural, aspek ekonomi, aspek agama, dan aspek pendidikan. kesimpulan dari penelitian R. A. Choirunnisa terdapat gerakan feminis yang lebih banyak bergerak ke arah aliran feminisme radikal dan liberal, hal itu terlihat dari beberapa gerakan feminis yang tergambar pada tokoh-tokoh yang terdapat dalam novel tersebut.

Selanjutnya penelitian yang berjudul, "Feminisme dalam Novel Bibir Merah Karya Achmad Munif" dilakukan oleh (Indayani, 2014) dipublikasikan pada jurnal Buana Bastra, Vol. 1, No. 1, April 2014. Berdasarkan penelitian yang dilakukan oleh Indayani dapat disimpulkan bahwa perilaku tokoh dalam novel Bibir Merah karya Achmad Munif merupakan reaksi Rumanti terhadap perlakuan lingkungannya, seperti masa lalu, pengalaman yang ia alami begitu menyakitkan. Hanya pengalaman hidup dan perubahan nasibnya yang membawa ia maju dalam segala hal. Sikap tokoh dalam novel Bibir Merah karya Achmad Munif merupakan perbuatan Rumanti berdasarkan keyakinannya atas lika-liku hidupnya. Bagaimana ia bersikap dalam menghadapi kehidupan. Rasa kasih sayang yang begitu dalam, ia curahkan untuk adiknya. Tutur bahasa dalam novel Bibir Merah karya Achmad Munif merupakan tutur bahasa tokoh yang lemah lembut. Ia mengeluarkan inner beautynya sebagai perempuan 


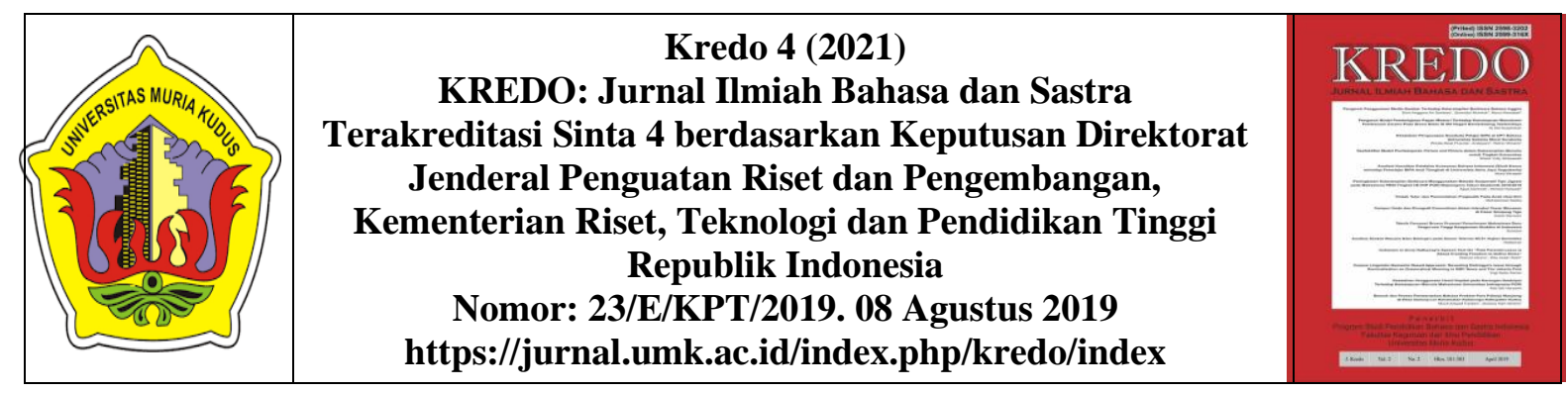

yang umumnya dimiliki oleh seorang perempuan.

Kemudian penelitian yang serupa berjudul, "Feminisme dalam Novel Perempuan Berkalung Sorban Karya Abidah El Khalieqy" dilakukan oleh Rani Nuraeni (2017:124), dipublikasikan pada jurnal Diksatrasia, Vol. 1, No. 2, Agustus 2017. Berdasarkan penelitian yang dilakukan oleh Rani Nuraeni dapat disimpulkan bahwa hasil penelitian dari unsur feminisme sastra adalah marginalisasi terhadap perempuan terjadi dalam setiap kehidupan seperti yang diceritakan dalam isi cerita novel tersebut. Marginalisasi merupakan batasanbatasan yang diterima oleh perempuan. Nilai-nilai patriarki yang sangat kental membuat kaum perempuan mengalami diskriminasi dalam setiap kehidupan yang dijalani.

Marginalisasi dalam novel Perempuan Berkalung Sorban banyak diceritakan di dalam lingkungan keluarga, dimulai dari anak perempuan yang sejak kecil dunia bermainnya sudah dibatasi oleh aturan-aturan keluarga dan budaya, larangan-larangan yang diberikan sangat membatasi kehidupan kaum perempuan, sedangkan anak laki-laki lebih mempunyai hak yang bebas melakukan hal apapun yang mereka sukai, tidak terhalang oleh aturan-aturan budayanya, tidak seperti kaum perempuan. Marginalisasi juga diperkuat oleh adat istiadat.
Selanjutnya subordinasi terhadap perempuan yang beranggapan bahwa perempuan itu irasional atau emosional sehingga perempuan tidak bisa tampil memimpin, dan berakibat munculnya sikap yang menempatkan perempuan pada posisi yang tidak penting, dan yang membedakan kaum perempuan dan laki-laki, terlebih bagi kaum lakilaki akan mendapatkan prioritas utama. Praktik seperti ini sesungguhnya berangkat dari kesadaran gender yang tidak adil, seakan-akan perempuan hanya ditakdirkan untuk menduduki posisi di bawah kaum laki-laki. Perempuan dilarang bersekolah tinggi dan hanya kaum laki-laki saja yang bisa mendapatkan pendidikan yang lebih tinggi, seperti terlihat tokoh-tokoh perempuan dalam novel Perempuan Berkalung Sorban yang tidak berpendidikan tinggi. Perempuan hanya ditaksirkan untuk menjalankan perintah lelaki dan hanya boleh melakukan seluruh peraturan dan tidak diizinkan mengikutcampuri masalah laki-laki.

Selanjutnya yaitu stereotipe adalah pelebelan atau penandaan terhadap kelompok atau jenis kelamin tertentu dan hal tersebut jarang sekali berpihak kepada kaum perempuan. Bentuk stereotipe yang terdapat dalam novel Perempuan Berkalung Sorban yaitu anggapan bahwa perempuan itu penggoda, yang merugikan dan menimbulkan ketidakadilan terhadap kaum perempuan. Masyarakat memiliki 


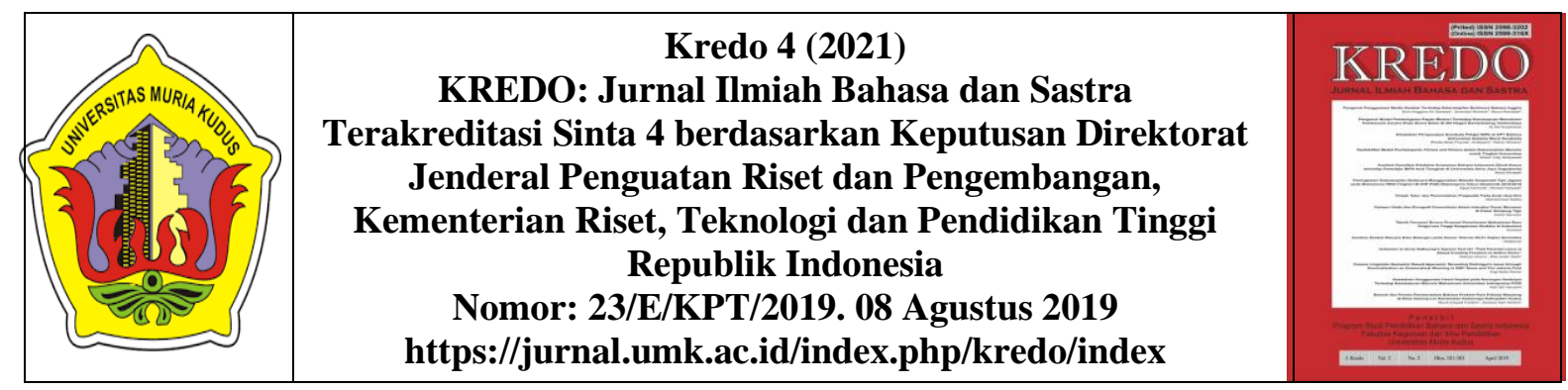

anggapan bahwa tugas utama kaum perempuan adalah berdiam di rumah melayani suami. Stereotipe terhadap kaum perempuan terjadi di mana banyak peraturan keagamaan, kultur dan kebiasaan masyarakat yang dikembangkan karena stereotipe tersebut. Betapa sempitnya pemikiran banyak orang yang sudah muncul sejak dulu, yang menilai arti sebuah kata perempuan. Perempuan dianggap makhluk bodoh dan selalu seperti itu dari masa ke masa. Perempuan tidak mempunyai akal seperti laki-laki. Perempuan selalu jadi nomor dua yang kedudukannya jauh di bawah laki-laki.

Selanjutnya yaitu kekerasan terhadap semua perempuan pada dasarnya berasal dari berbagai sumber, yang disebabkan oleh anggapan gender. Kekerasan yang dilakukan oleh gender ini disebut gender-related violance. Pada dasarnya, kekerasan gender disebabkan oleh ketidaksetaraan kekuatan yang ada dalam masyarakat. Kekerasan terhadap perempuan yang diceritakan dalam novel Perempuan Berkalung Sorban lebih dilakukan terhadap kekerasan batin yang menimbulkan rasa sakit hati yang dialami oleh perempuan. Dengan rasa sakit yang dideritanya bahkan perempuan tidak boleh melakukan halhal yang dilakukan kaum laki-laki.

Selanjutnya adalah beban kerja terhadap kaum perempuan yaitu adanya anggapan bahwa kaum perempuan

537 | Jurnal Kredo

Vol. 4 No. 22021 memiliki sifat memelihara dan rajin, serta tidak cocok untuk menjadi kepala rumah tangga, berakibat bahwa semua pekerjaan domestik rumah tangga menjadi tanggung jawab kaum perempuan. Konsekuensinya, banyak kaum perempuan yang harus bekerja keras menjaga kebersihan dan kerapihan rumah tangganya, mulai dari membersihkan rumah dan mengepel lantai, memasak, mencuci, mencari air untuk mandi hingga mengurus anak.

Menurut (Noor, 2011), mengemukakan bahwa kerangka berpikir merupakan model konseptual mengenai bagaimana satu teori berhungan di antara berbagai faktor yang telah diidentifikasikan penting terhadap masalah penelitian. dalam kerangka berpikir, peneliti harus menguraikan konsep atau variabel penelitiannya secara lebih perinci. Tidak hanya mengidentifikasikan variabel tadi, tetapi juga menjelaskan keterkaitan di antara variabel tersebut. Dalam menguraikan kerangka berpikir, peneliti tidak sekadar memfokuskan pada variabel penelitiannya saja tetapi juga harus menghubungkan konsep penelitian dalam kerangka yang lebih luas lagi. Pertautan antarvariabel tersebut, selanjutnya dirumuskan ke dalam bentuk paradigma penelitian. Oleh karena itu, pada setiap penyusunan paradigma penelitian didasarkan pada kerangka berpikir. 


Kredo 4 (2021)
KREDO: Jurnal Ilmiah Bahasa dan Sastra
Terakreditasi Sinta 4 berdasarkan Keputusan Direktorat
Jenderal Penguatan Riset dan Pengembangan,
Kementerian Riset, Teknologi dan Pendidikan Tinggi
Republik Indonesia
Nomor: 23/E/KPT/2019. 08 Agustus 2019
https://jurnal.umk.ac.id/index.php/kredo/index
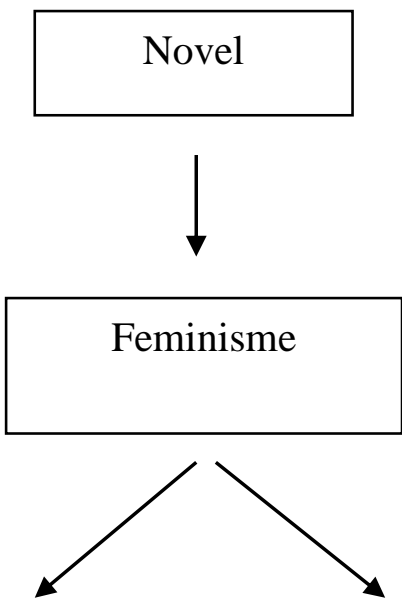

\begin{tabular}{|c|}
\hline Aliran-Aliran \\
Feminisme
\end{tabular}

Dari bagan di atas, dapat disimpulkan bahwa novel yang diambil dalam penelitian ini adalah novel Cinta 2 Kodi karya Asma Nadia dengan menggunakan kajian feminisme. Feminisme di dalam penelitian ini terdiri dari beberapa aliran-aliran dan aspek-aspek feminisme. Aliran-aliran feminisme meliputi: (1) feminisme radikal; (2) feminisme marxis dan sosialis; (3) feminisme liberal; (4) feminisme psikoanalisis; (5) feminisme eksistensialis, (6) feminisme postmodern; (7) feminisme multikultural dan global; dan (8) feminisme ekofeminisme. Dari beberapa aliran tersebut, novel ini cenderung ke aliran feminisme marxis dan sosialis. Sedangkan aspek-aspek feminisme meliputi: (1) aspek sosial-kultural; (2) aspek ekonomi; (3) aspek politik; (4) aspek pendidikan; (5) aspek religius; dan (6) aspek hukum. Dari aspek-aspek tersebut, penulis meneliti empat aspek yaitu aspek sosial-kultural, aspek ekonomi, aspek agama dan aspek pendidikan yang menjadi fokus penelitian.

\section{KAJIAN TEORI}

\section{Pengertian Novel}

Novel merupakan bentuk karya sastra yang bersinonim dengan fiksi. Sebutan novel berasal dari bahasa Italia novella (yang dalam bahasa Jerman: novelle). Dewasa ini istilah novella dan novelle mengandung pengertian yang sama dengan istilah Indonesia novelet yang berarti sebuah karya prosa fiksi yang panjangnya cukup, tidak terlalu panjang, namun tidak terlalu pendek (Nurgiyantoro, 2015).

Menurut Diki (2020) Novel sebagai wujud karya sastra tercipta dari kisah nyata dan sebagai bentuk imajinasi pengarang terkait suatu kenyataan. Karya sastra dipandang sebagai refleksi dari berbagai kehidupan di masyarakat yang mengandung berbagai fenomena masalah.

Novel merupakan struktur yang bermakna. Novel tidak sekedar merupakan serangkaian tulisan yang menggairahkan ketika dibaca, tetapi merupakan struktur pikiran yang tersusun dari unsur-unsur yang padu (Sugihastuti, 2002). Selanjutnya Hill 


\begin{tabular}{|c|c|c|}
\hline & $\begin{array}{c}\text { Kredo } 4(2021) \\
\text { KREDO: Jurnal Ilmiah Bahasa dan Sastra } \\
\text { Terakreditasi Sinta } 4 \text { berdasarkan Keputusan Direktorat } \\
\text { Jenderal Penguatan Riset dan Pengembangan, } \\
\text { Kementerian Riset, Teknologi dan Pendidikan Tinggi } \\
\text { Republik Indonesia } \\
\text { Nomor: 23/E/KPT/2019. 08 Agustus 2019 } \\
\text { https://jurnal.umk.ac.id/index.php/kredo/index }\end{array}$ & 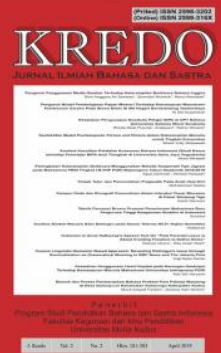 \\
\hline
\end{tabular}

dikutip (Sugihastuti, 2002) mengungkapkan bahwa novel sebagai salah satu bentuk cerita rekaan, yang merupakan sebuah struktur yang kompleks. Oleh karena itu, untuk memahaminya, novel tersebut harus dianalisis.

Novel sebagai salah satu jenis karya sastra hadir dari tulisan pengarang yang merupakan bagian dari masyarakat. Melalui karyanya pengarang mengajak pembaca untuk menghayati dan menangkap fenomena kehidupan yang dijalankan oleh tokohtokoh dalam cerita (Setiawan, 2018).

Kridalaksana dikutip (Sofia, 2009), mengungkapkan pula bahwa novel memiliki batasan sebagai sebuah karangan prosa yang panjang yang mengandung rangkaian cerita kehidupan seseorang dengan orang-orang di sekelilingnya dengan menonjolkan watak dan sifat setiap pelaku.

Dari beberapa pendapat di atas, dapat disimpulkan bahwa novel merupakan suatu karya prosa fiksi yang lengkap yang menceritakan struktur pikiran secara utuh dari kehidupan seseorang, baik penulis ataupun tokoh di dalam cerita dengan menonjolkan watak dan sifat setiap perilaku sehingga dapat melahirkan suatu konflik dengan jalan cerita yang dikemas dengan menarik.

\section{Pengertian Feminisme}

Feminisme adalah teori tentang persamaan antara laki-laki dan perempuan di bidang politik, ekonomi, dan sosial atau kegiatan terorganisasi yang memperjuangkan hak-hak dan kepentingan perempuan (Goefe dikutip (Sugihastuti, 2002)). Sementara itu, Budianta dikutip (Sofia, 2009), mengartikan feminisme sebagai suatu kritik ideologis terhadap cara pandang yang mengabaikan permasalahan ketimpangan dan ketidakadilan dalam pemberian peran dan identitas sosial berdasarkan perbedaan jenis kelamin. Menurut Humm dikutip (Wiyatmi, 2012), feminisme menggabungkan doktrin persamaan hak bagi perempuan yang menjadi gerakan yang terorganisasi untuk mencapai hak asasi perempuan, dengan sebuah ideologi transformasi sosial yang bertujuan untuk menciptakan dunia bagi perempuan. Selanjutnya Humm menyatakan bahwa feminisme merupakan ideologi pembebasan perempuan dengan keyakinan bahwa perempuan mengalami ketidakadilan karena jenis kelaminnya.

Berdasarkan beberapa pendapat di atas, dapat disimpulkan bahwa feminisme adalah suatu gerakan perempuan yang menuntut persamaan hak sepenuhnya antara kaum perempuan dan kaum laki-laki untuk mengubah keadaan tanpa mengubah kodrat sebagai perempuan. 


\begin{tabular}{|c|c|c|} 
Kredo 4 (2021) \\
KREDO: Jurnal Ilmiah Bahasa dan Sastra \\
Terakreditasi Sinta 4 berdasarkan Keputusan Direktorat \\
Jenderal Penguatan Riset dan Pengembangan, \\
Kementerian Riset, Teknologi dan Pendidikan Tinggi \\
Republik Indonesia \\
Nomor: 23/E/KPT/2019. 08 Agustus 2019 \\
https://jurnal.umk.ac.id/index.php/kredo/index
\end{tabular}

\section{Aspek-Aspek Feminisme}

Menurut (Endraswara, 2013), analisis karya sastra dengan menggunakan kajian feminisme yang difokuskan adalah kedudukan dan peran tokoh perempuan dalam sastra, ketertinggalan kaum perempuan dalam segala aspek kehidupan, termasuk pendidikan dan aktivitas kemasyarakatan, memperhatikan faktor pembaca sastra, bagaimana tanggapan pembaca terhadap emansipasi wanita dalam sastra. Hal ini sesuai dengan perkataan (Susanto, 2016), bahwa isu utama dalam kajian kesusastraan yang berhubungan dengan feminisme adalah tentang posisi, kedudukan, pengalaman hidup dan bentuk-bentuk tulisan perempuan dalam sastra.

Berdasarkan aliran-aliran yang telah dijelaskan di atas dapat diketahui bahwa terdapat beberapa aspek yang diperjuangkan kaum feminis di antaranya sebagai berikut.

\section{Aspek Sosial-kultural}

Aspek sosial-kultural adalah yang berhubungan dengan kemasyarakatan yang dibangun dan hidup dalam suatu masyarakat. Di dalam bidang sosial, hak-hak perempuan sangat terbatas. Perempuan dianggap sebagai makhluk kedua sesudah laki-laki, perempuan dianggap lemah, bersifat halus, pasif, ketergantungan, emosional, tidak mandiri, keibuan, penyabar dan sejenisnya sehingga perempuan diangap selayaknya bekerja di sektor domestik (Nugroho, 2008).

Feminisme dalam aspek ini, merupakan gerakan yang dilakukan oleh perempuan dalam upaya penghapusan sudut pandang yang memojokkan perempuan. Contohnya, perempuan sebagai ibu rumah tangga, menimbulkan pandangan masyarakat bahwa perempuan makhluk jenis kedua sesudah laki-laki sehingga keberadaannya di tengah-tengah masyarakat tidak diperhitungkan.

\section{Aspek Ekonomi}

Aspek di bidang ekonomi membahas tentang perempuan dan karir. Pada zaman sekarang telah banyak perempuan yang memiliki peran ganda yaitu sebagai istri sekaligus pencari nafkah. Hal ini tampak dari banyaknya sarjana perempuan yang mampu memadukan antara pernikahan dan profesi (Djajanegara, 1995).

Di dalam masyarakat patriarki terdapat keyakinan bahwa pekerjaan yang dianggap masyarakat sebagai jenis pekerjaan perempuan, seperti semua pekerjaan domestik, dianggap lebih rendah dibandingkan dengan pekerjaan yang dianggap masyarakat sebagai jenis pekerjaan perempuan, pekerjaan perempuan dianggap lebih rendah dibandingkan dengan pekerjaan yang dianggap sebagai pekerjaan laki-laki dan dikategorikan sebagai pekerjaan 


\begin{tabular}{|c|c|c|}
\hline & $\begin{array}{c}\text { Kredo 4 (2021) } \\
\text { KREDO: Jurnal Ilmiah Bahasa dan Sastra } \\
\text { Terakreditasi Sinta } 4 \text { berdasarkan Keputusan Direktorat } \\
\text { Jenderal Penguatan Riset dan Pengembangan, } \\
\text { Kementerian Riset, Teknologi dan Pendidikan Tinggi } \\
\text { Republik Indonesia } \\
\text { Nomor: 23/E/KPT/2019. 08 Agustus 2019 } \\
\text { https://jurnal.umk.ac.id/index.php/kredo/index }\end{array}$ & $\begin{array}{l}\square \\
\square \\
\square \\
\square \\
\square\end{array}$ \\
\hline
\end{tabular}

yang bukan produktif sehingga kurang diperhitungkan dalam statistik ekonomi negara (Nugroho, 2008).

Sampai saat ini perempuan berkarir merupakan hal yang menarik untuk dibicarakan karena sebagian besar lapangan kerja tertutup bagi wanita. Kalaupun dia diberi kesempatan untuk mencari nafkah, upah yang diterimanya jauh lebih rendah daripada upah yang diterima kaum laki-laki (Susanto, 2016)

Hal ini disebabkan oleh anggapan masyarakat bahwa kaum lakilaki adalah pencari nafkah sehingga bertanggung jawab untuk memenuhi kebutuhan hidup istri dan anaknya sedangkan perempuan hanya dipandang sebagai pelengkap dan laki-laki pun beranggapan memang sudah menjadi kewajiban bagi perempuan harus bekerja mengatur urusan rumah tangga, seperti membersihkan rumah, mencuci baju, memasak, merawat anak dan kewajiban melayani suami (Arivia dikutip Wiyatmi, 2012).

\section{Aspek Politik}

(Djajanegara, 2003)

mengemukakan bahwa dunia politik yang sudah lama dikuasai oleh laki-laki pernah memberi kesempatan kepada perempuan untuk ikut terlibat di dalamnya. Kaum laki-laki pada umumnya menolak membiarkan perempuan mengambil alih kedudukan mereka. Kaum laki-laki selalu menghambat perjuangan kaum feminisme Kaum feminisme dalam aspek politik memperjuangkan haknya untuk memperoleh kesempatan dalam dunia politik, misalnya kebebasan untuk mengungkapkan pendapat, mempunyai hak penuh atas dirinya untuk memutuskan apa yang diinginkannya dan kesempatan untuk menjadi pemimpin dalam suatu bidang kehidupan.

\section{Aspek Pendidikan}

Pendidikan merupakan proses pengubahan sikap dan tingkah laku baik secara formal ataupun tidak formal. Pandangan masyarakat, perempuan itu emosional, irasional, dan pandangan ini mengakibatkan perempuan dikondisikan tidak tampil sebagai pemimpin. Diskriminasi terhadap perempuan muncul dalam segala bentuk yang berbeda antara satu tempat dengan tempat yang lainnya. Di Jawa dan Sunda ada anggapan bahwa perempuan tidak usah sekolah tinggi-tinggi, karena akhirnya akan ke dapur juga. Selain itu, dalam lingkungan rumah tangga yang ekonominya pas-pasan, masih terdengar keputusan keluarga yang diskriminatif, yaitu mendahulukan pendidikan anak laki-lakinya dari pada anak perempuan (Darma, Aliah, 2009).

Hal ini berakibat buruk bagi perempuan, yaitu adanya anggapan untuk menepatkan perempuan pada posisi yang tidak penting, hendaknya perempuan diberi hak untuk menuntut

\section{$541 \mid$ Jurnal Kredo \\ Vol. 4 No. 22021}




\begin{tabular}{|c|c|c|} 
Kredo 4 (2021) \\
KREDO: Jurnal Ilmiah Bahasa dan Sastra \\
Terakreditasi Sinta 4 berdasarkan Keputusan Direktorat \\
Jenderal Penguatan Riset dan Pengembangan, \\
Kementerian Riset, Teknologi dan Pendidikan Tinggi \\
Republik Indonesia \\
Nomor: 23/E/KPT/2019. 08 Agustus 2019 \\
https://jurnal.umk.ac.id/index.php/kredo/index
\end{tabular}

ilmu sesuai keinginannya dan setara dengan laki-laki.

Feminisme dalam aspek pendidikan adalah gerakan kaum perempuan yang menuntut persamaan pemberian kesempatan dan untuk mengembangkan diri terutama dalam memperoleh pendidikan di sekolah.

\section{Aspek Agama}

Dalam kehidupan berbudaya, manusia menciptakan berbagai aturan main untuk mengatur hubungan antarmanusia dan hubungan dengan sang pencipta. Agama merupakan salah satu wujud dari kebudayaan manusia. Seperti hasil budaya manusia yang lain, agama dikembangkan berdasarkan pola pikir yang sudah ada dalam masyarakat. Ideologi gender juga mewarnai munculnya agama-agama dan perkembangannya. Dari ajaran beberapa agama dapat diketahui seberapa jauh agama mempunyai andil memantapkan akses negatif dari ideologi gender. Salah satu akses negatif dari ideologi gender adalah terbentuknya struktur budaya patriarki. Dalam budaya ini kedudukan perempuan ditentukan lebih rendah daripada laki-laki atau dalam masyarakat terjadi dominasi laki-laki (Bariah, 2007).

Dalam agama Islam, gerakan feminis muslim harus berpegang teguh pada paradigma agama Islam agar tidak menjadi sekuler (Nugroho, 2008). Menurut (Sofia, 2009), hal yang menjadi permasalahan feminis muslim adalah ajaran Islam dan peran gender dalam hubungannya dengan keluarga dan masyarakat dalam tema-tema yang menyangkut perkawinan, perceraian, hak-hak pendidikan, profesi dan sebagainya.

\section{Aspek Hukum}

Dunia hukum yang sejak berabad-abad dikuasai dan dikendalikan oleh kaum wanita yang sama sekali tidak mempunyai pengalaman. Kaum pria yang pada umumnya menolak membiarkan wanita menggeser atau mengambil alih kedudukan mereka selalu menghambat perjuangan para feminis (Djajanegara, 2003). Melihat posisi mereka yang sulit, kaum feminis sadar bahwa satu-satunya jalan untuk mampu terjun ke dunia hukum adalah lewat pendidikan. Mereka berharap, melalui pendidikan pengetahuan mereka menjadi luas dan bisa mengetahui likuliku berbagai bidang, termasuk bidang hukum yang selalu didominasi kaum laki-laki.

Untuk menjadi seorang hakim hendaklah adil dan membela kebenaran. Seorang hakim akan adil bila selalu berpegang pada kebenaran, kejujuran dan tak terpengaruh sentimennya. Dalam melakukan pekerjaan mestilah bersifat objektif. Seorang ahli hukum ia hanya mencari kebenaran, tidak menambah-nambah, tidak pula menguranginya. Bila baik dikatakan 


\begin{tabular}{|c|c|c|} 
Kredo 4 (2021) \\
KREDO: Jurnal Ilmiah Bahasa dan Sastra \\
Terakreditasi Sinta 4 berdasarkan Keputusan Direktorat \\
Jenderal Penguatan Riset dan Pengembangan, \\
Kementerian Riset, Teknologi dan Pendidikan Tinggi \\
Republik Indonesia \\
Nomor: 23/E/KPT/2019. 08 Agustus 2019 \\
https://jurnal.umk.ac.id/index.php/kredo/index
\end{tabular}

baik, dengan alasan-alasan dan sandaran yang dapat diterima akal budi manusia. Dalam menghakimi hendaklah adil tidak memandang bulu, baik itu kawan maupun lawan. Bila seseorang melakukan kesalahan maka katakanlah bersalah, bila tidak harus dikatakan tidak. Jadi seorang hakim adalah seorang pembela kebenaran.

Feminisme dalam aspek hukum adalah gerakan kaum wanita yang membela kebenaran tidak memandang bulu, baik itu kawan maupun lawan ia harus adil. Kaum feminisme dalam aspek hukum ia mempunyai hak penuh untuk membela kebenaran.

\section{METODE PENELITIAN}

(Siswatoro, 2010) menjelaskan bahwa metode merupakan cara yang digunakan peneliti di dalam usaha memecahkan masalah yang diteliti. Kemudian menurut Nawawi dikutip (Siswatoro, 2010) metode deskriptif adalah prosedur pemecahan masalah yang diselidiki dengan menggambarkan keadaan subjek atau objek penelitian pada saat sekarang berdasarkan fakta yang sebenarnya.

Berdasarkan penjelasan di atas, metode yang digunakan dalam penelitian ini adalah metode deskriptif dengan pendekatan feminisme karena peneliti mencoba untuk menggambarkan atau mendeskripsikan feminisme yang terkandung dalam

\section{3 | Jurnal Kredo}

Vol. 4 No. 22021 novel Cinta 2 Kodi karya Asma Nadia yang menitikberatkan pada tokoh Kartika selaku tokoh utama perempuan dan juga melalui tokoh-tokoh lainnya yang ada dalam novel tersebut.

(Adi, 2011), menyatakan bahwa data merupakan hal pokok dalam suatu penelitian karena dari data tersebutlah suatu penelitian dapat dilakukan. Adapun data dari penelitian ini adalah cerita yang terdapat dalam novel Cinta 2 Kodi karya Asma Nadia, khususnya kajian feminisme dalam aspek sosialkultural, aspek ekonomi, aspek agama, dan aspek pendidikan.

Menurut (Arikunto, 2010), Sumber data adalah subjek dari mana data dapat diperoleh. Adapun yang menjadi sumber data dalam penelitian ini yaitu sebuah novel berjudul Cinta 2 Kodi karya Asma Nadia. Novel tersebut diterbitkan oleh AsmaNadia Publishing House, terbit pertama kali pada tahun 2017 hingga sekarang sudah diterbitkan ulang sebanyak delapan kali. Tebal novel sebanyak 378 halaman dengan ukuran panjang 20,5 $\mathrm{cm}$ dan lebar 14 cm. Selain itu juga buku-buku yang berkaitan dengan kajian feminisme.

Data dikumpulkan dengan menggunakan teknik dokumentasi. "Teknik dokumentasi adalah mencari data mengenai hal-hal atau variabel yang berupa catatan, transkip, bukubuku dan lain sebagainya (Arikunto, 2010). 


\begin{tabular}{|c|c|c|} 
Kredo 4 (2021) \\
KREDO: Jurnal Ilmiah Bahasa dan Sastra \\
Terakreditasi Sinta 4 berdasarkan Keputusan Direktorat \\
Jenderal Penguatan Riset dan Pengembangan, \\
Kementerian Riset, Teknologi dan Pendidikan Tinggi \\
Republik Indonesia \\
Nomor: 23/E/KPT/2019. 08 Agustus 2019 \\
https://jurnal.umk.ac.id/index.php/kredo/index
\end{tabular}

Data yang dikumpulkan melalui teknik dokumentasi dalam penelitian ini berasal dari isi novel Cinta 2 Kodi karya Asma Nadia yang menjadi pusat kajian. Sementara itu diperlukan juga bukubuku dan sumber lainnya yang berkaitan dengan feminisme dalam karya sastra. Buku-buku yang berkaitan dengan feminisme yaitu buku Kritik Sastra Feminis karya Wiyatmi, buku Aplikasi Kritik Sastra Feminis karya Adib Sofia, buku Gender dan Strategi Pengurus Utamanya di Indonesia karya Riant Nugroho, buku Teori Apresiasi Sastra karya Sugihastuti dan lain-lain.

Teknik keabsahan data dalam penelitian ini menggunakan triangulasi data. Menurut (Gunawan, 2013), Triangulasi adalah istilah yang diperkenalkan oleh Denzin (1978) dengan meminjam peristilahan dari dunia navigasi dan militer, yang merujuk pada penggabungan berbagai metode dalam suatu kajian tentang satu gejala tertentu. Keandalan dan kesahihan data dijamin dengan membandingkan data yang diperoleh dari satu sumber atau metode tertentu, dengan data yang didapat dari sumber atau metode lain.

Triangulasi mencari dengan cepat pengujian data yang sudah ada dalam memperkuat tafsir dan meningkatkan kebijakan, serta program yang berbasis pada bukti yang telah tersedia. Triangulasi adalah suatu pendekatan analisa data yang mensintesa data dari berbagai sumber. Triangulasi bukan bertujuan mencari kebenaran, tetapi meningkatkan pemahaman peneliti terhadap data dan fakta yang dimilikinya. Berdasarkan uraian di atas, dapat disimpulkan triangulasi merupakan suatu cara mendapatkan data yang benar-benar absah dengan menggunakan pendekatan metode ganda. Triangulasi sebagai teknik pemeriksaan keabsahan data dengan cara memanfaatkan sesuatu yang lain di luar data itu sendiri. Selanjutnya, Denzin dikutip (Gunawan, 2013), membedakan empat macam triangulasi, yaitu (1) triangulasi sumber adalah menggali kebenaran informan tertentu melalui berbagai sumber memperoleh data. (2) triangulasi metode adalah usaha mengecek keabsahan data, atau mengecek keabsahan temuan peneliti. (3) triangulasi peneliti adalah menggunakan lebih dari satu peneliti dalam mengadakan observasi atau wawancara dan yang selanjutnya (4) triangulasi teoritik adalah memanfaatkan dua teori atau lebih untuk diadu dan dipadu.

Teknik analisis data yang digunakan dalam penelitian ini adalah teknik analisis konten. Menurut (Endraswara, 2013), “Analisis konten adalah strategi untuk menangkap pesan karya sastra". Tujuan analisis konten adalah membuat inferensi. Analisis konten digunakan apabila sipeneliti 


\begin{tabular}{|c|c|c|} 
Kredo 4 (2021) \\
KREDO: Jurnal Ilmiah Bahasa dan Sastra \\
Terakreditasi Sinta 4 berdasarkan Keputusan Direktorat \\
Jenderal Penguatan Riset dan Pengembangan, \\
Kementerian Riset, Teknologi dan Pendidikan Tinggi \\
Republik Indonesia \\
Nomor: 23/E/KPT/2019. 08 Agustus 2019 \\
https://jurnal.umk.ac.id/index.php/kredo/index
\end{tabular}

hendak mengungkap, memahami, dan menangkap pesan karya sastra.

Dalam analisis konten ditempuh langkah-langkah sebagai berikut.

1) Membaca novel Cinta 2 Kodi karya Asma Nadia secara berulang-ulang dengan teliti dan memahaminya.

2) Membuat sinopsis novel Cinta 2 Kodi karya Asma Nadia.

3) Menganalisis cerita untuk mengetahui aspek sosial-kultural, aspek ekonomi, aspek agama, dan aspek pendidikan yang terdapat dalam novel Cinta 2 Kodi karya Asma Nadia.

4) Mendeskripsikan hasil kajian feminisme yang terdapat dalam novel Cinta 2 Kodi karya Asma Nadia.

5) Mengklasifikasikan aspek-aspek yang terdapat dalam kajian feminisme dalam novel Cinta 2 Kodi karya Asma Nadia disertai dengan kutipan-kutipan teks.

6) Membuat pembahasan tentang novel Cinta 2 Kodi karya Asma Nadia.

7) Membuat kesimpulan tentang novel Cinta 2 Kodi karya Asma Nadia.

\section{HASIL DAN PEMBAHASAN}

Berdasarkan hasil analisis data, feminisme dalam aspek sosial-kultural pada novel Cinta 2 Kodi karya Asma Nadia adalah membicarakan hubungan sosial dan budaya yang dibangun dan

545 | Jurnal Kredo

Vol. 4 No. 22021 berkembang di masyarakat. Dalam novel ini feminisme sosial yang dikaji melalui tokoh Kartika dan Aryani yang sama-sama memiliki sifat yang sabar, lemah lembut dan menggambarkan sosok perempuan yang kuat, mampu melawan penindasan dan melakukan tindakan pembelaan terhadap dirinya sendiri. Tokoh Kartika mampu menjadi sosok feminis yang sabar dan kuat dalam melewati berbagai kesulitan yang dialami pada saat menjelang acara lamarannya dengan Farid yang harus batal dikarenakan perseteruan kedua orang tua. Orang tua Farid yang hanya mengizinkan menikah jika dengan cara adat, hal ini ditolak oleh orang tua Kartika hingga tidak merestui hubungan keduanya untuk melangsungkan pernikahan. Mereka menikah tanpa restu orang tua Farid, Kartika dengan sifat sabarnya mampu bertahan dengan sifat mertua yang selalu memaksa melalui Farid untuk menggugurkan bayi yang ada dalam kandungannya yang masih berusia 3 bulan. Melalui tindakan yang dilakukan Farid menjelaskan kesamaan pendapat dengan (Nugroho, 2008), bahwa dalam bidang sosial hakhak perempuan sangat terbatas. Perempuan dianggap sebagai makhluk kedua setelah laki-laki. Perempuan dianggap lemah, bersifat halus dan pasif, ketergantungan, emosional, tidak mandiri, keibuan, penyabar, dan sebagainya, sehingga perempuan 


\begin{tabular}{|c|c|c|}
\hline & $\begin{array}{c}\text { Kredo 4 (2021) } \\
\text { KREDO: Jurnal Ilmiah Bahasa dan Sastra } \\
\text { Terakreditasi Sinta } 4 \text { berdasarkan Keputusan Direktorat } \\
\text { Jenderal Penguatan Riset dan Pengembangan, } \\
\text { Kementerian Riset, Teknologi dan Pendidikan Tinggi } \\
\text { Republik Indonesia } \\
\text { Nomor: 23/E/KPT/2019. 08 Agustus 2019 } \\
\text { https://jurnal.umk.ac.id/index.php/kredo/index }\end{array}$ & $\begin{array}{l}\square \\
\square \\
\square \\
\square \\
\square\end{array}$ \\
\hline
\end{tabular}

dianggap selayaknya bekerja di sektor domestik.

Kartika merupakan sosok feminis yang mampu mengambil keputusan melalui tindakannya menolak perintah suami demi melindungi bayi yang ada di dalam kandungannya dan ikhlas menerima resiko jika harus kehilangan suami. Baginya tidak ada satu manusia pun berhak menghilangkan jiwa yang telah Allah titipkan. Sejak awal Farid dan Kartika tidak mendapatkan restu dari orang tua Farid karena saat datang melamar, orang tua Farid mengajukan syarat yang menjadi tradisi adat suku orang Minang dan syarat itu tidak dipenuhi oleh orang tua Kartika. Namun, pada akhirnya orang tua Farid merestui hubungan keduanya karena ia menyadari bahwa kebahagiaan seorang anak jauh lebih utama dibandingkan tradisi adat. Selanjutnya Aryani juga merupakan tokoh feminis yang sabar dan kuat serta selalu taat pada perintah suami demi kebahagiaan rumah tangganya. Hal ini terlihat bahwa Aryani tidak pernah mendapatkan perlakuan yang baik dari suaminya. Ia tidak mendapatkan kesempatan untuk tampil di publik, hanya ditugaskan oleh suami untuk menjaga anak-anak serta mengurus suami dan rumah tangga seperti memasak, mencuci, menyapu, mengepel, dan lain sebagainya. Menurut suaminya, perempuan hanyalah untuk mengurus rumah tangga saja, tidak bisa tampil di publik. Dalam hal mengurus rumah tangga suaminya tidak pernah mau membantu, Bagja sibuk dengan urusannya sementara Aryani selalu dianggap tidak becus dalam bekerja. Bagja merupakan sosok laki-laki yang kontra terhadap feminis. Manusia selalu punya batas kesabaran, Aryani berani untuk mengambil tindakan. Saat Aryani telah mengantar ketiga anaknya ke jenjang pernikahan saat itu pula Aryani mengambil keputusan untuk bercerai dari Bagja. Hal ini merupakan tindakan pembelaan atas dirinya sendiri.

Aspek ekonomi pada novel Cinta 2 Kodi karya Asma Nadia menunjukkan bahwa perempuan dapat memiliki karir yang baik dan mampu tampil di publik seperti laki-laki. Hal ini dapat membuktikan bahwa perempuan juga mampu memiliki pekerjaan di bidang publik seperti halnya laki-laki. Perempuan tidak selalu memiliki pekerjaan di bidang domestik, karenanya perempuan pun dapat diperhitungkan sebagaimana laki-laki. Sama halnya dengan yang dikatakan oleh (Nugroho, 2008), dalam masyarakat patriarki terdapat keyakinan bahwa pekerjaan yang dianggap masyarakat sebagai jenis pekerjaan perempuan, seperti semua pekerjaan domestik, dianggap lebih rendah dibandingkan dengan pekerjaan yang dianggap masyarakat sebagai jenis pekerjaan perempuan, pekerjaan 


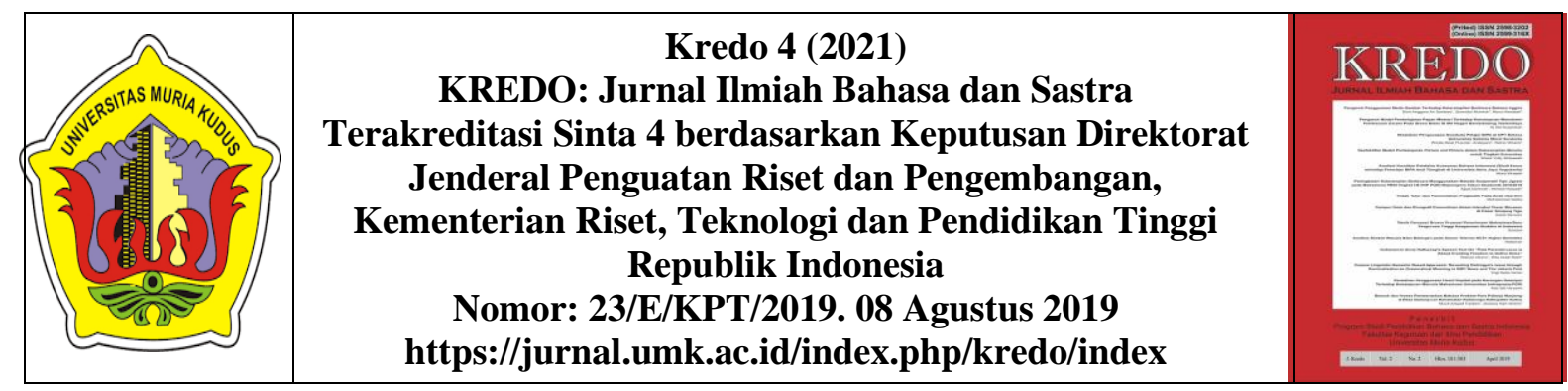

perempuan dianggap lebih rendah dibandingkan dengan pekerjaan yang dianggap sebagai pekerjaan laki-laki, dan dikategorikan sebagai pekerjaan yang bukan produktif sehingga kurang diperhitungkan dalam statistik ekonomi negara.

Hal ini disebabkan oleh anggapan masyarakat bahawa kaum laki-laki adalah pencari nafkah sehingga bertanggungjawab untuk memenuhi kebutuhan hidup istri dan anaknya sedangkan perempuan hanya dipandang sebagai pelengkap. Laki-laki pun beranggapan memang sudah menjadi kewajiban perempuan untuk bekerja mengatur urusan rumah tangga, seperti membersihkan rumah, mencuci baju,memasak, merawat anak dan kewajiban mealayani suami (Arivia dalam Wiyatmi, 2012).

Seorang feminis yang memiliki karir yang baik dapat dilihat melalui tokoh Kartika. Kartika adalah perempuan feminis yang memiliki profesi sebagai seorang pengusaha busana muslim anak dan dewasa yang sukses dalam karirnya. Usahanya berkembang sangat pesat dengan dibanjiri pesanan-pesanan oleh pelanggannya. Walaupun memiliki karir yang baik, Kartika tidak lantas melupakan hakikat dirinya sebagai perempuan, istri sekaligus seorang ibu. Kartika merupakan tokoh feminis yang mandiri dan tidak ingin bergantung pada laki-laki. Kartika mampu membagi perannya dengan baik, yaitu sebagaimana yang dikatakan oleh (Djajanegara, 1995), bahwa pada zaman sekarang telah banyak perempuan yang memiliki peran ganda yaitu sebagai istri sekaligus pencari nafkah. Hal ini tampak dari banyaknya sarjana perempuan yang mampu memadukan antara pernikahan dan profesi.

Melalui tokoh Kartika dapat dibuktikan bahwa perempuan tidak harus mempunyai predikat lulusan dari luar negeri untuk bisa menunjang karir yang baik, selagi ada tekad dan kemampuan yang dimiliki, perempuan dapat membangun karir yang lebih baik. Selain itu, melalui tokoh Kartika dapat dapat dibuktikan bahwa perempuan tidak memiliki batasan dalam berkakrir dan memiliki hak untuk tampil di publik seperti laki-laki. Tokoh Kartika merupakan gambaran sosok perempuan cerdas, mandiri, aktif, tidak suka bergantung pada laki-laki. Dengan demikian, dapat disimpulkan bahwa Kartika merupakan contoh perempuan feminis yang mampu berkarir di sektor publik seperti halnya laki-laki.

Aspek agama pada novel Cinta 2 Kodi karya Asma Nadia menunjukkan bahwa tokoh perempuan dalam novel tersebut merupakan perempuan yang taat beragama. Tokoh utama perempuan yaitu Kartika adalah sosok muslimah berjilbab yang aktif, mandiri, cerdas dan taat beragama. Kartika dan Farid 


\begin{tabular}{|c|c|c|}
\hline & $\begin{array}{c}\text { Kredo } 4(2021) \\
\text { KREDO: Jurnal Ilmiah Bahasa dan Sastra } \\
\text { Terakreditasi Sinta } 4 \text { berdasarkan Keputusan Direktorat } \\
\text { Jenderal Penguatan Riset dan Pengembangan, } \\
\text { Kementerian Riset, Teknologi dan Pendidikan Tinggi } \\
\text { Republik Indonesia } \\
\text { Nomor: 23/E/KPT/2019. 08 Agustus 2019 } \\
\text { https://jurnal.umk.ac.id/index.php/kredo/index }\end{array}$ & 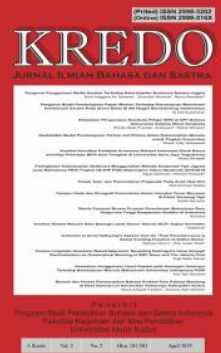 \\
\hline
\end{tabular}

merupakan pasangan suami dan isteri yang taat pada perintah agama. Bagi keduanya sholat adalah hal yang utama, tidak boleh sedikit pun dikalahkan oleh urusan bisnis. Mereka selalu menjalankan ibadah sesuai dengan perintah Islam dan tanpa merasa terbebani karena memang pada hakikatnya agama adalah untuk mempermudah bukan untuk menyulitkan. Sebagaimana yang dikatakan (Nugroho, 2008), bahwa dalam agama Islam, gerakan feminis muslim harus berpegang teguh pada paradigma agama Islam agar tidak menjadi sekuler. Dengan menjadi seorang muslim yang taat beragama mereka akan mampu menjadi manusia yang lebih baik.

Melalui tokoh Kartika, terlihat bahwa dirinya adalah sosok perempuan muslimah yang cerdas, sabar, mandiri, dan taat beribadah. Meskipun Kartika sibuk dengan Karirnya ia tidak pernah sekalipun lupa untuk beribadah dan selalu berusaha untuk menjalankan ibadah tepat pada waktunya. Saat pertama kali membangun bisnis baju muslim anak ia selalu kesulitan dalam menitipkan baju ke daerah-daerah karena banyak toko yang tidak mau menerima baju tanpa merek. Dengan penuh kesabaran ia menjalani setiap proses yang dilewati. Bersama dengan Farid, meski sedang di mana pun mereka tidak ragu untuk menghentikan perjalanan mereka terlebih dahulu untuk mencari Masjid agar bisa melaksanakan ibadah baik itu salat wajib maupun salat sunah. Farid adalah sosok suami yang mendukung kaum feminis, ia selalu mendukung dan membantu karir Kartika sampai akhirnya ia bisa menjadi seorang pengusaha yang sukses. Kartika dan Farid merupakan pasangan suami dan istri yang taat pada perintah agama bahwa keduanya tidak pernah meninggalkan waktu sholat, bagi mereka salat adalah yang utama. Selain itu, doa-doa juga selalu mereka panjatkan kepada sang pencipta di kala sedang dalam kesusahan dan juga pada saat senang. Mereka tidak pernah lupa selalu bersyukur kepada sang pencipta

Aspek pendidikan pada novel Cinta 2 Kodi karya Asma Nadia menunjukkan bahwa perempuan dalam novel tersebut tidak memiliki kesempatan yang sama dengan laki-laki dalam arti perempuan tidak diberikan kebebasan untuk menentukan pendidikan yang diinginkan. Di dalam novel ini, ayah Kartika, Bagja, sebagai orang tua yang lebih mendahulukan pendidikan anak laki-laki dibandingkan anak perempuan. Sebagaimana yang dikatakan oleh (Darma, Aliah, 2009), bahwa pendidikan merupakan proses pengubahan sikap dan tingkah laku baik secara formal ataupun tidak formal. Pandangan masyarakat, perempuan itu emosional, irasional, dan pandangan ini mengakibatkan perempuan dikondisikan 


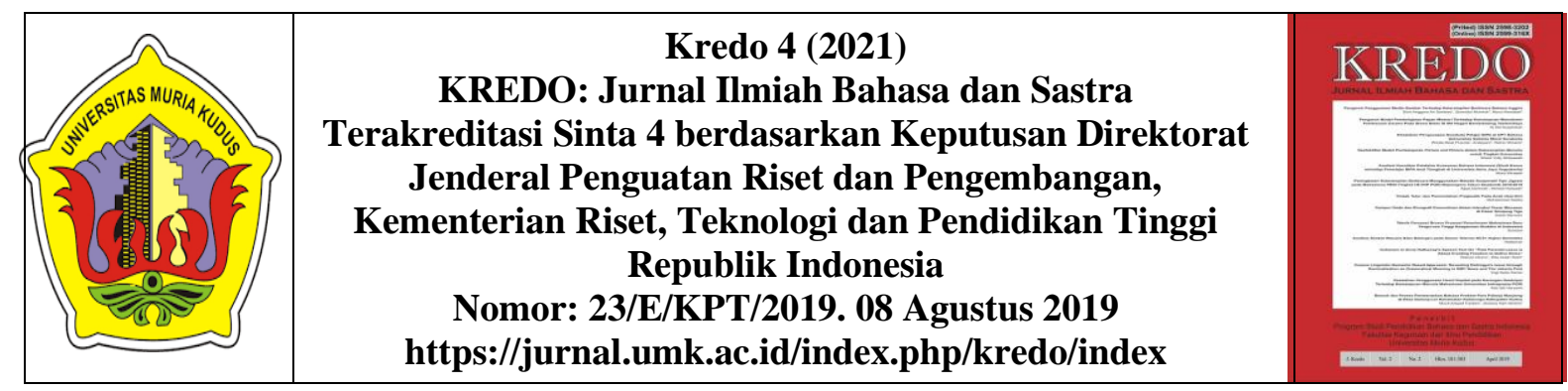

tidak tampil sebagai pemimpin. Diskriminasi terhadap perempuan muncul dalam segala bentuk yang berbeda antara satu tempat dengan tempat yang lainnya. Di Jawa dan Sunda ada anggapan bahwa perempuan tidak usah sekolah tinggi-tinggi, karena akhirnya akan ke dapur juga. Selain itu, dalam lingkungan rumah tangga yang ekonominya pas-pasan, masih terdengar keputusan keluarga yang diskriminatif, yaitu mendahulukan pendidikan anak laki-lakinya dari pada anak perempuan. Hal ini berakibat buruk bagi perempuan, yaitu adanya anggapan untuk menempatkan perempuan pada posisi yang tidak penting, hendaknya perempuan diberi hak untuk menuntut ilmu sesuai keinginannya dan setara dengan laki-laki.

Dalam novel ini, ketidakadilan dalam dunia pendidikan dilakukan oleh Ayah Kartika yang bernama Bagja. Gender yang menjadi permasalahan utamanya dalam dunia pendidikan. Dalam novel ini dapat dilihat bahwa Ayah Kartika merupakan sosok seorang Ayah yang mendiskriminasi pendidikan bagi anak-anaknya. Baginya, hanya anak laki-lakinya saja yang boleh melanjutkan pendidikan di luar negeri. Sedangkan anak perempuan tidak diperbolehkan untuk melanjutkan pendidikan di luar negeri. Berbeda dengan Ibu Kartika merupakan tokoh feminis yang selalu mendukung semua keinginan anak-anaknya, Ia selalu bersikap adil, tanpa membeda-bedakan anak laki-laki ataupun perempuan, dan mendukung apa yang menjadi keinginan anak-anaknya. Anak perempuan dapat diberi hak untuk menuntut ilmu sesuai dengan keinginannya dan setara dengan laki-laki. Pandangan serupa juga terlihat dari tokoh Kartika dan Farid yang memiliki pandangan bahwa perempuan harus diberi hak untuk menuntut ilmu sesuai keinginannya dan setara dengan laki-laki agar tidak memiliki batasan di dalam dunia pendidikan. Melalui tokoh Kartika dapat disimpulkan bahwa perempuan tidak harus memiliki predikat lulusan luar negeri untuk dapat menunjang karir yang baik. dengan tekad dan kemampuannya, Kartika yang bukan lulusan dari luar negeri kini dapat menjadi seorang pengusaha yang sukses.

Cerita dalam novel Cinta 2 Kodi karya Asma Nadia ini masih sering terjadi di dalam kehidupan masyarakat Indonesia hingga saat ini. Kita masih sering mendengar diskriminasi bagi kaum perempuan di dalam rumah tangga, kaum laki-laki yang berkuasa atas perempuan. Seperti tokoh Bagja yang selalu mendiskriminasi tokoh Aryani. Dalam novel ini Bagja merupakan tokoh yang kontra feminis. Kedudukannya sebagai kepala keluarga membuat Bagja merasa berkuasa di dalam rumah tangga. Aryani, isterinya, seolah-olah harus tunduk atas segala perintahnya. Ia juga harus selalu 


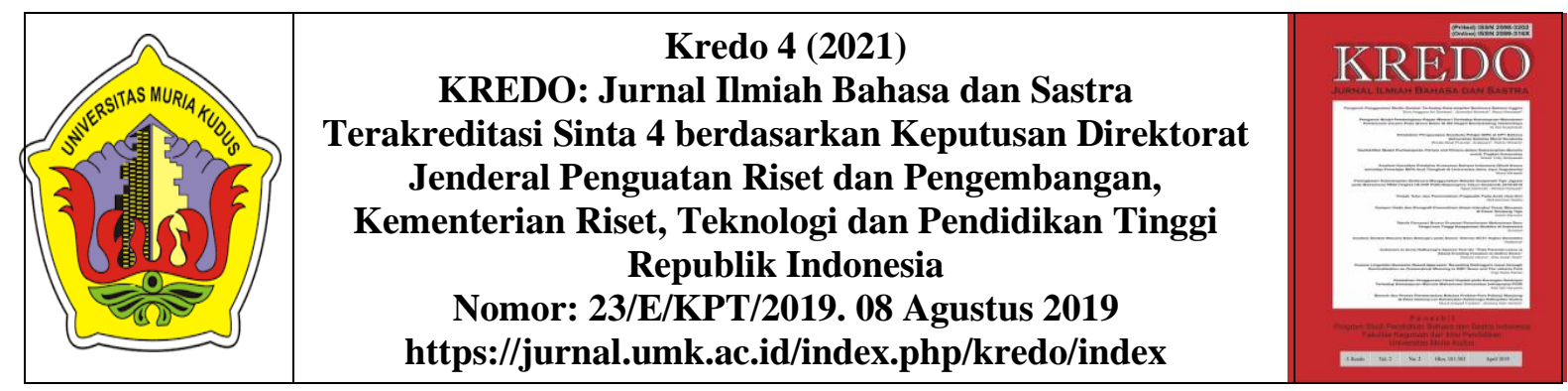

melayani suaminya dengan baik layaknya seorang raja. Hal seperti itu masih banyak terjadi dalam masyarakat Indonesia ataupun di dalam kehidupan sehari-hari di lingkungan kita.

Seharusnya kaum perempuan dan laki-laki dapat memiliki kedudukan yang setara yaitu mempunyai hak yang sama dalam hal apapun, tidak ada larangan bagi kaum perempuan untuk mencapai segala keinginannya. Tokoh Kartika dan Farid dalam novel ini sebagai suami dan isteri sama-sama saling mendukung. Farid merupakan tokoh yang pro feminis, Ia selalu mendukung apapun yang dilakukan Kartika. Saat Kartika mempunyai niat untuk membangun sebuah bisnis pun Farid adalah orang pertama yang mendukung niat bai Kartika, bukan melarang yang menjadi keinginan isterinya. Sampai akhirnya bisnis Kartika berkembang dengan sangat pesat hingga menjadi bisnis yang besar, semua itu berkat restu dan dukungan dari suaminya.

\section{SIMPULAN}

Berdasarkan hasil analisis data dalam novel Cinta 2 Kodi karya Asma
Nadia dapat disimpulkan bahwa Feminisme dalam aspek sosial-kultural menunjukkan bahwa perempuan tidak selamanya menjadi "makhluk kedua" setelah laki-laki. perempuan dapat sejajar dengan laki-laki jika dirinya mau untuk berusaha. Feminisme dalam aspek ekonomi menunjukkan bahwa perempuan mampu untuk berkarir di sektor publik seperti halnya laki-laki. perempuan mampu memiliki peran ganda baik itu sebagai ibu rumah tangga maupun wanita karir. Feminisme dalam aspek agama menunjukkan bahwa perempuan ataupun laki-laki tidak ada halangan untuk melakukan ibadah. Hal ini dikarenakan kesuksesan adalah hasil yang diperoleh dari setiap proses ibadah yang dilakukan. Feminisme dalam aspek pendidikan menunjukkan bahwa perempuan dianggap tidak harus memiliki pendidikan yang hebat karena pada akhirnya akan bekerja sebagai ibu rumah tangga. Namun, walaupun perempuan tidak memiliki pendidikan yang hebat selama dirinya yakin pada kemampuannya mereka akan memiliki masa depan yang cerah seperti laki-laki.

\section{DAFTAR PUSTAKA}

Adi, I. R. 2011. Fiksi Populer: Teori dan Metode. Yogyakarta: Pustaka Pelajar. 


Kredo 4 (2021)
KREDO: Jurnal Ilmiah Bahasa dan Sastra
Terakreditasi Sinta 4 berdasarkan Keputusan Direktorat
Jenderal Penguatan Riset dan Pengembangan,
Kementerian Riset, Teknologi dan Pendidikan Tinggi
Republik Indonesia
Nomor: 23/E/KPT/2019. 08 Agustus 2019
https://jurnal.umk.ac.id/index.php/kredo/index

Arikunto, S. 2010. Prosedur Penelitian Suatu Pendekatan Praktik. Jakarta: Rineka Cipta.

Bariah, K. 2007. Feminisme dalam Novel Veil Of Roses: Kerudung Merah Karya Laura Fitzerald. Universitas PGRI Palembang.

Darma, Aliah, Y. 2009. Analisis Wacana Kritis. Bandung: Yrama Widya.

Departemen Pendidikan Nasional. 2008. Kamus Besar Bahasa Indonesia Pusat Bahasa (Edisi IV). Jakarta: PT Gramedia Pustaka Utama.

Djajanegara, S. 1995. Cintra Wanita dalam Lima Novel Terbaik Sinclair Lewis dan Gerakan Wanita Amerika. Depok: Fakultas Sastra Universitas Indonesia.

Djajanegara, S. 2003. Kritik Sastra Feminis: Sebuah Pengantar. Jakarta: PT Gramedia Pustaka Utama.

Endraswara, S. 2013. Metodologi Penelitian Sastra; Epistemologi, Model, Teori, dan Penerapannya. Yogyakarta: CAPS.

Febrianto, Diki. 2020. Hegemoni Kekuasaan dalam Novel Koplak Karya Oka Rusmini: Kajian Sosiologi Sastra KREDO: Jurnal Ilmiah Bahasa Dan Sastra Volume 3 No. 2 2020. DOI: 10.24176/kredo.3i2.4347.

Gunawan, I. 2013. Metode Penelitian Kualitatif: Teori \& Praktik. Jakarta: PT Bumi Aksara.

Indayani. 2014. Feminisme dalam Novel Bibir Merah Karya Achmad Munif. Jurnal Buana Bastra.

Krissandi, A. 2019. Resistensi Pengarang melalui Konstruksi Perempuan Timur dalam "Kartini” Karya Putu Wijaya. KREDO : Jurnal Ilmiah Bahasa Dan Sastra, 3 (1). Kudus: Universitas Muria Kudus

Narasati, R. 2019. The Causes and Effects Of Women's Superiority Towards Men As Seen In Aristhophanes' Lysistrata. KREDO : Jurnal Ilmiah Bahasa Dan Sastra, $3(1), 17-35$.

$551 \mid$ Jurnal Kredo

Vol. 4 No. 22021 


Kredo 4 (2021)
KREDO: Jurnal Ilmiah Bahasa dan Sastra
Terakreditasi Sinta 4 berdasarkan Keputusan Direktorat
Jenderal Penguatan Riset dan Pengembangan,
Kementerian Riset, Teknologi dan Pendidikan Tinggi
Republik Indonesia
Nomor: 23/E/KPT/2019. 08 Agustus 2019
https://jurnal.umk.ac.id/index.php/kredo/index

Noor, J. 2011. Metodologi Penelitian. Jakarta: Kencana.

Nugroho, R. 2008. Gender dan Strategi Pengurus Utamanya di Indonesia. Yogyakarta: Pustaka Belajar.

Nurgiyantoro, B. 2015. Teori Pengkajian Fiksi. Yogyakarta: Gajah Mada University Press.

Setiawan, A. 2018. Pandangan Hidup Wanita Jawa Dalam Novel Bekisar Merah Karya Ahmad Tohari. KREDO: Jurnal Ilmiah Bahasa Dan Sastra, 1(2). https://doi.org/10.24176/kredo.v1i2.2113

Siswatoro. 2010. Metode Penelitian Sastra: Analisis Puisi. Surakarta: Sebelas Maret University Press.

Sofia, A. 2009. Aplikasi Kritik Sastra Feminis: Perempuan dalam Karya-Karya Kuntowijoyo. Yogyakarta: Citra Pustaka.

Sugihastuti. 2002. Teori Apresiasi Sastra. Yogyakarta: Pustaka Belajar.

Susanto, D. 2016. Pengantar Kajian Sastra. Yogyakarta: CAPS.

Wiyatmi. 2012. Kritik Sastra Feminis: Teori dan Aplikasinya dalam Sastra Indonesia. Yogyakarta: Ombak. 